\title{
Eksplorasi Kemampuan Awal Statistis Mahasiswa dalam Topik
} Statistika Deskriptif

\author{
Dian Cahyawati $^{\left.{ }^{*}\right)}$, Wahyudin ${ }^{2}$, \& Sufyani Prabawanto ${ }^{3}$ \\ ${ }^{1}$ Universitas Sriwijaya, ${ }^{2,3}$ Universitas Pendidikan Indonesia
}

\section{INFO ARTICLES}

\section{Article History:}

Received: $17-02-2020$

Revised: 27-05-2020

Approved: 03-06-2020

Publish Online: 16-06-2020

\section{Key Words:}

korelasi, mixed method, penalaran statistis, pengetahuan awal, validitas

This article is licensed under a Creative Commons AttributionShareAlike 4.0 International License.

\begin{abstract}
This article outlines the results of exploration of the students statistical prior knowledge ability in dealing with statistical information and solving descriptive statistical problems. The study was conducted in the even semester of 2018/2019 year and used a quasi-experimental design. The student's statistical prior knowledge (SPK) ability was explored by analizing the results of student work in completing test. Exploration results showed that there were some differences in the way of answering test and they SPK. Students who have the high-SPK category could completely understand the concept of measurement scale and applied it appropriately to the problem, could estimate the answer and process the solutions in a logical way, comprehend the concepts and linkage measures of centralization, and could interpret statistical information and provided the relevant conclusions with their perspective on the problem. Students who came from the lower-SPK group have not yet understood the concept of measurement scales, they could determine statistical measures and estimate the answer but in unclear ways, still interpreting statistical information in a limited way.
\end{abstract}

\begin{abstract}
Abstrak: Artikel ini menguraikan hasil eksplorasi terhadap data kemampuan awal statistis mahasiswa dalam menghadapi informasi statistik dan menyelesaikan permasalahan statistika deskriptif. Penelitian dilaksanakan pada semester genap tahun akademik 2018/2019 dengan desain kuasieksperimen. Kemampuan awal statistis (KAS) mahasiswa dieksplorasi dari hasil pekerjaan mahasiswa terhadap soal tes uraian. Hasil eksplorasi menunjukkan adanya perbedaan cara kerja dan KAS mahasiswa. Mahasiswa yang mewakili kategori KAS-tinggi sudah dapat memahami konsep skala pengukuran dan menerapkannya secara tepat terhadap permasalahan, dapat memperkirakan jawaban dan proses solusi dengan cara yang logis, memahami konsep dan keterkaitan ukuran-ukuran pemusatan, serta dapat menafsirkan informasi statistik dan memberikan kesimpulan yang relevan menggunakan cara pandang mereka terhadap permasalahan. Mahasiswa dari kelompok KAS-rendah belum memahami konsep skala pengukuran, cenderung dapat menentukan ukuran-ukuran statistik dan memperkirakan jawaban namun dengan cara yang belum jelas, cenderung masih menginterpretasikan informasi statistik secara terbatas.
\end{abstract}

Correspondence Address: Jl. Palembang-Prabumulih KM 32 Indralaya 30662, Kab. Ogan Ilir, Provinsi Sumatera Selatan, Indonesia; e-mail: dianc_mipa@unsri.ac.id

How to Cite (APA $6^{\text {th }}$ Style): Cahyawati, D., Wahyudin, Prabawanto, S. (2020). Eksplorasi Kemampuan Awal Statistis Mahasiswa dalam Topik Statistika Deskriptif. JKPM (Jurnal Kajian Pendidikan Matematika), Vol (Issue): 201-212.

Copyright: Cahyawati D, Wahyudin, Prabawanto S., (2020).

Competing Interests Disclosures: The authors declare that they have no significant competing financial, professional or personal interests that might have influenced the performance or presentation of the work described in this manuscript. 


\section{PENDAHULUAN}

Salah satu topik yang paling menantang dalam mempelajari konsep-konsep statistika adalah topik statistika inferensi (Park, 2018). Beberapa mahasiswa ada yang mengalami kesulitan pemahaman dan kesalahan konsep pada topik tersebut. Hal itu disebabkan oleh ide-ide abstrak dalam statistika yang berkaitan dengan konsep pengujian hipotesis dan posisi statistika inferensial yang biasanya terletak pada akhir silabus (Park, 2018) yang disitasi dari Garfield \& Ben-Zvi (2008). Hal lain yang menjadi faktor penghambat adalah kesulitan dalam mengenali parameter populasi pada masalah pengujian hipotesis yang dihadapi (Thompson \& Liu, 2005). Berdasar pada pengalaman peneliti dari setiap hasil ujian pada topik statistika inferensial, masih ada mahasiswa yang belum konsisten membedakan parameter dan statistik, masih ada mahasiswa yang belum dapat menyatakan hipotesis yang sesuai dengan permasalahan, dan masih ada yang belum memahami arah hipotesis yang diuji sehingga terjadi kekeliruan dalam menerapkan aturan inferensi.

Beberapa peneliti yang banyak berkontribusi dalam praktek pendidikan statistika seperti (Ben-Zvi, 2011; Ben-Zvi \& Garfield, 2004; DelMas, 2002, 2006; Garfield, 1993, 1995, 2002) sejak lama telah memberikan saran untuk mengatasi kesulitan dan meningkatkan kemampuan penalaran statistis mahasiswa yaitu dengan mengkaji ulang dan memperhatikan model atau metode pembelajaran yang diterapkan di kelas. Model pembelajaran tradisional dikaji ulang penerapannya dan dibandingkan dengan model pembelajaran lainnya untuk melihat perbedaan pengaruhnya terhadap kemampuan penalaran statistis. Penelitian (Bateiha, Marchionda, \& Autin, 2020) membandingkan model pembelajaran tradisional dan model pembelajaran aktif berbasis diskusi untuk melihat perbedaan pengaruhnya dalam melaksanakan kuliah pengantar statistika. Namun demikian, selain model pembelajaran ada faktor lain yang dapat mempengaruhi proses belajar dalam berbagai materi, termasuk materi statistika, yaitu media pembelajaran (Nadiyah, Wijaya, \& Hakim, 2019) dan pengetahuan awal statistis yang dimiliki pembelajar. Pengetahuan awal yang dimiliki pembelajar sebelum mengikuti pembelajaran disebut prior knowledge (Dochy, Segers, \& Buehl, 1999; Gurlitt \& Renk1, 2010) yang dapat diistilahkan dengan kemampuan awal.

Pengetahuan awal atau kemampuan awal adalah sejumlah pengetahuan yang telah dimiliki seseorang dalam memori jangka panjangnya (Li, 2018). Level pengetahuan awal seseorang mengenai topik tertentu dapat mempengaruhi prestasi atau kemampuannya dalam topik yang berkaitan dengan pengetahuan awal tersebut. Sejalan dengan (Valstar, Griswold, \& Porter, 2019) yang menyatakan bahwa pengetahuan awal sebagai salah satu faktor penentu kesuksesan atau prestasi. Pengetahuan awal yang diperlukan mahasiswa dalam mempelajari topik statistika inferensial antara lain adalah pengetahuan dalam topik statistika deskriptif. Materinya antara lain tentang populasi, sampel, parameter, statistik, skala pengukuran, menentukan ukuran-ukuran pemusatan dan penyebaran, menyajikan data dalam bentuk tabel, diagram, atau grafik, serta menginterpretasikannya. Setelah mempelajari dan memahami materi-materi itu, diharapkan mahasiswa dapat memiliki pengetahuan awal yang cukup untuk dapat mencapai kemampuan penalaran statistis yang optimal. Belum tercapainya kemampuan penalaran statistis yang memuaskan seperti yang dihasilkan dalam penelitian (Rohana \& Ningsih, 2020) dapat diungkapkan lebih lanjut dengan mengeksplorasi pengetahuan awal mahasiswa yang mengikuti pembelajaran terkait.

Penelitian ini bertujuan untuk mengeksplorasi pengetahuan awal mahasiswa dalam topik statistika deskriptif sebelum melanjutkan penelitian untuk mengukur kemampuan penalaran ststistis. Pengetahuan awal statistis diukur dengan soal tes tulis kemampuan awal statistis. Hasil eksplorasi ini dapat dijadikan bahan pertimbangan dalam melaksanakan pembelajaran lanjutan khususnya yang berkaitan dengan statistika inferensial. 


\section{METODE}

Penelitian ini dirancang menggunakan metode mixed-method (Castro, Kellison, Boyd, \& Kopak, 2010; Creswell, 2008; Kadambari, Kumar, Zayapragassarazan, \& Parija, 2018; Kanga, Njeru, Wachera, \& Jedidah, 2015) dengan desain sekuensial eksplanatori. Fase pertama dilaksanakan metode kuantitatif dengan metode kuasi-eksperimen desain faktorial pretest-postest dua kelompok. Fase kedua dilaksanakan metode kualitatif dengan pendekatan Grounded Theory.

Partisipan atau subjek penelitian adalah mahasiswa aktif S1 program studi pendidikan matematika di salah satu universitas swasta di Kota Bandung. Mereka terdaftar sebagai peserta mata kuliah Statistika untuk Penelitian pada semester genap tahun akademik 2018/2019. Ada sebanyak 70 orang mahasiswa yang terbagi menjadi dua kelas pembelajaran. Setiap kelas pembelajaran terdiri dari 35 orang mahasiswa.

Mahasiswa pada kedua kelas pembelajaran diberikan soal tes tulis penentuan grup penelitian. Tes tulis berisi materi statistika deskriptif yang telah diberikan di sekolah menengah. Berdasarkan hasil analisis terhadap skor hasil tes tersebut diperoleh keputusan bahwa kemampuan mahasiswa di antara kedua kelas pembelajaran tidak menunjukkan perbedaan. Dengan demikian penentuan kelompok eksperimen dan kelompok kontrol dilakukan secara acak.

Kemampuan awal statistis (KAS) diukur dengan soal tes tulis yang memuat delapan soal terkait materi statistika deskriptif. Delapan soal ini memuat delapan indikator yang disusun menjadi empat nomor soal tes. Soal pertama (dua sub soal) memuat indikator "mengenali dan mengidentifikasi konsep". Soal kedua, ketiga, dan keempat berturut-turut memuat indikator "memperkirakan jawaban dan proses solusi", "mengajukan lawan contoh", "menuliskan fakta, hubungan/pola, menarik kesimpulan logis dan menjelaskannya". Skor maksimal yang dapat diperoleh dari hasil pengerjaan soal tes ini adalah 45 dan dikonversi menjadi nilai pada rentang $0-100$.

Instrumen penelitian untuk mengukur variabel harus memenuhi persyaratan sebagai instrumen yang baik (Ruseffendi, 2005) yaitu memenuhi syarat reliabel dan valid (Creswell, 2008, 2014; Kerlinger, 1986). Instrumen yang digunakan harus dipastikan benar-benar mengukur variabel yang seharusnya diukur dan mengukur secara akurat (Sekaran, 2006; Sekaran \& Bougie, 2013).

Instrumen tes KAS telah melalui proses validasi ahli, uji coba, dan pengujian validitas dan reliabilitas instrumen. Hasil pengujian statistik terhadap nilai validasi muka dan validasi isi dari dua validator menunjukkan signifikansi hasil uji Mann-Whitney adanya kesamaan pertimbangan dari kedua validator insstrumen KAS dengan nilai signifikansi (Asymt. Sig) yang lebih besar dari 0,05. Selanjutnya, tahap uji coba empiris instrumen tes KAS dilakukan dengan memberikan soal tes kepada 13 mahasiswa non-sampel penelitian. Hasil uji coba tersebut memberikan nilai koefisien korelasi Pearson (Jackson, 2006) hasil tes KAS dengan data nilai IPK mahasiswa peserta uji coba sebesar 0,60 dan signifikan secara statistik ( $\operatorname{sig}=$ 0,03). Koefisien korelasi menunjukkan tingkat keeratan hubungan antara kedua variabel (Walpole, Myers, \& Myers, 2011) dengan nilai sebesar 0,60 termasuk pada kategori tingkat keeratan yang sedang. Selain itu, koefisien reliabilitas instrumen diperoleh sebesar 0,701 yang memenuhi syarat uji konsistensi internal suatu instrumen karena nilai koefisien reliabilitasnya lebih besar dari 0,7 (Furr, 2011; Hair, Black, Babin, \& Anderson, 2010). Dengan demikian, instrumen tes KAS telah memenuhi tahap uji validitas dan reliabilitas sehingga instrumen dapat digunakan untuk tahap penelitian selanjutnya. 


\section{HASIL}

Hasil yang diuraikan pada artikel ini merupakan sebagian hasil penelitian yang dilaksanakan pada fase pertama dan fase kedua. Sebagaimana diuraikan pada bagian metode, fase pertama penelitian menggunakan metode kuantitatif dan fase kedua menggunakan metode kualitatif.

\section{Subjek Penelitian}

Subjek penelitian adalah mahasiswa peserta pembelajaran mata kuliah Statistika untuk Penelitian pada semester enam (genap) tahun akademik 2018/2019. Ada 70 orang mahasiswa yang terbagi dalam dua kelas pembelajaran yang sudah terbentuk sejak semester pertama. Masing-masing kelas pembelajaran terdiri dari 35 mahasiswa.

Berdasar pada prestasi akademik mahasiswa yang diukur dengan nilai Indeks Prestasi Kumulatif (IPK), sebaran frekuensi kelompok prestasi akademis (IPK) ditunjukkan dengan Gambar 1.

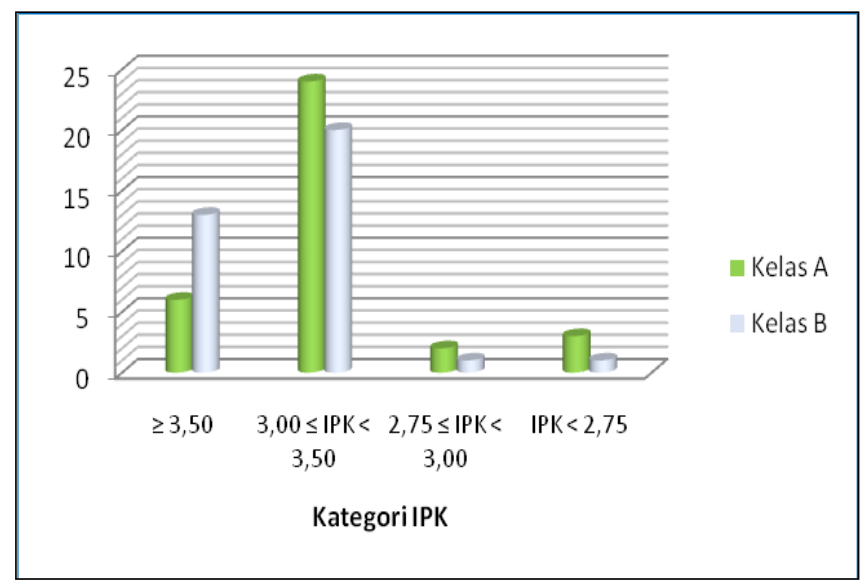

Gambar 1. Prestasi Akademis Mahasiswa berdasar pada MK nilai IPK Tabel 1.

Rata-rata IPK dan simpangan baku rata-rata untuk kedua kelas pembelajaran ditampilkan pada

Tabel 1. IPK Mahasiswa Kelas A dan Kelas B

\begin{tabular}{ccc}
\hline \multirow{2}{*}{ Kelas } & \multicolumn{2}{c}{ Nilai IPK } \\
\cline { 2 - 3 } & Rata-Rata & Simp. Baku \\
\hline A & 3,20 & 0,43 \\
B & 3,42 & 0,34 \\
\hline
\end{tabular}

\section{Tes Kemampuan Awal Statistis}

Nilai rata-rata hasil tes KAS pada kelompok eksperimen dan kelompok kontrol ditampilkan pada Tabel 2. 
Tabel 2.

Nilai Hasil Tes KAS pada Kedua Kelompok Pembelajaran

\begin{tabular}{lcccc}
\hline \multirow{2}{*}{ Kelompok } & \multicolumn{3}{c}{ Nilai KAS } \\
& Min & Maks & Rata-Rata & Simpangan Baku \\
\hline Eksperimen & 46,67 & 95,56 & 73,39 & 12,39 \\
Kontrol & 26,67 & 91,11 & 68,63 & 14,57 \\
\hline
\end{tabular}

Secara deskripsi, nilai rata-rata hasil tes KAS pada kelompok eksperimen lebih tinggi dibandingkan dengan kelompok kontrol, meskipun perbedaannya hanya 4,76 poin. Simpangan baku nilai KAS pada kelompok kontrol lebih besar dibandingkan dengan kelompok eksperimen, dapat menjadi indikasi bahwa nilai hasil tes KAS mahasiswa pada kelompok kontrol lebih bervariasi dibandingkan dengan nilai hasil tes KAS pada kelompok eksperimen. Meskipun terdapat perbedaan nilai rata-rata KAS kedua kelompok pembelajaran, namun hasil pengujian hipotesis secara statistik menghasilkan $t_{\text {hitung }}=1,472$ dengan nilai signifikansi ( $\operatorname{sig}=0,146)$. Hal itu menunjukkan belum cukup bukti untuk menolak pernyataan bahwa kedua kelompok pembelajaran memiliki kemampuan awal statistis yang berbeda. Dengan kata lain, hasil pengujian secara statistik menunjukkan bahwa mahasiswa pada kedua kelompok pembelajaran memiliki kemampuan awal statistis yang sama.

Berdasar pada hasil tersebut, pengelompokan kemampuan awal statistis mahasiswa menjadi tiga kelompok KAS dapat menggunakan data nilai hasil tes KAS keseluruhan/gabungan mahasiswa. Ada 70 data nilai tes KAS mahasiswa dari kedua kelompok pembelajaran. Data nilai tersebut diurutkan kemudian dibagi tiga kelompok KAS (rendah, sedang, tinggi) dengan mempertimbangkan batas nilai dan banyaknya data untuk setiap kelompok. Batas nilai pengelompokan diperoleh dari data gabungan yang telah diurutkan.

Sebaran level KAS untuk kelompok eksperimen dan kelompok kontrol ditampilkan pada Gambar 2. Nilai hasil tes KAS yang tidak kurang dari 75 dikategorikan pada level KAS-tinggi. Nilai hasil tes KAS yang kurang dari 65 dikelompokkan pada level KAS-rendah. Sisanya dikelompokkan pada level KASsedang.

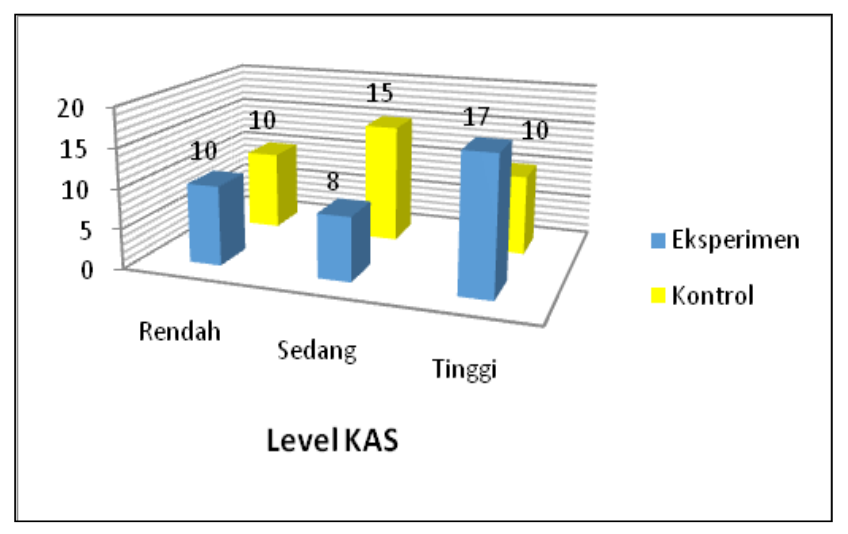

Gambar 2. Sebaran Mahasiswa berdasarkan Level KAS

\section{Hasil Pekerjaan Mahasiswa}


Instrumen tes KAS pada penelitian ini terdiri dari empat soal. Soal pertama dan kedua memuat dua indikator. Soal ketiga memuat satu indikator. Soal keempat memuat tiga indikator. Indikator pada soal pertama bertujuan untuk menunjukan pemahaman dan kemampuan membedakan empat tipe skala pengukuran serta dapat menerapkannya pada contoh permasalahan. Indikator pada soal kedua bertujuan untuk memperkirakan jawaban dari data yang disajikan dalam bentuk grafik dengan cara yang logis. Indikator pada soal ketiga bertujuan untuk memahami konsep ukuran pemusatan rata-rata, modus, dan median serta menyimpulkan keterkaitannya. Indikator pada soal keempat bertujuan untuk menentukan ukuran pemusatan dari data yang disajikan dalam bentuk diagram, menafsirkan diagram, dan memberikan kesimpulan yang relevan dan logis.

\section{a. Kelompok Level KAS-Tinggi}

M1 dan M2 adalah mahasiswa yang dipilih dari kelompok level KAS-tinggi. M1 berhasil menuliskan empat jenis skala pengukuran dengan tepat sebagai jawaban untuk indikator pertama pada Soal 1. Keempat jenis skala pengukuran itu berhasil diterapkan dengan benar pada tujuh dari delapan variabel yang diberikan.

Hasil pekerjaan M2 hampir sama dengan hasil pekerjaan M1 dalam menjawab Soal 1 tes KAS. M2 berhasil menuliskan dengan tepat empat jenis skala pengukuran dan menerapkannya terhadap variabel-variabel yang diberikan. Hasil identifikasi skala pengukuran untuk tujuh dari delapan variabel pada Soal 1 sudah benar.

Soal 1. Skala Pengukuran Data
a. Berdasarkan skala pengukuran data, tuliskan jenis data yang Anda ketahui.
b. Disajikan Tabel 1 yang berisi cuplikan informasi kelahiran di "Klinik Bersalin Mama". Untuk setiap kolom
variabel yang ada, tuliskanlah jenis skala pengukuran masing-masing variabel tersebut.
\begin{tabular}{|c|c|c|c|c|c|c|c|c|}
\hline $\begin{array}{c}\text { Usia } \\
\text { Ibu } \\
\text { No. } \\
\text { (tahun) }\end{array}$ & $\begin{array}{c}\text { Tingkat } \\
\text { Pendidikan }\end{array}$ & $\begin{array}{c}\text { Jenis } \\
\text { Persalinan }\end{array}$ & $\begin{array}{c}\text { Usia } \\
\text { Kehamilan } \\
\text { (minggu) }\end{array}$ & $\begin{array}{c}\text { Jumlah } \\
\text { Kehamilan } \\
\text { Sebelumnya }\end{array}$ & $\begin{array}{c}\text { Jumlah } \\
\text { Anak } \\
\text { LahirHldup }\end{array}$ & $\begin{array}{c}\text { Riwayat } \\
\text { Keguguran }\end{array}$ & $\begin{array}{c}\text { Berat Bayi } \\
\text { Lahir (gr) }\end{array}$ \\
\hline 1 & 19 & SD & Normal & 37 & 4 & 3 & Tidak & 3000 \\
\hline 2 & 27 & SMP & Normal & 37 & 2 & 1 & Tidak & 3000 \\
\hline 3 & 30 & SMA & Operasi & 40 & 5 & 1 & Tidak & 3600 \\
\hline 4 & 28 & SMP & Vacum & 36 & 3 & 1 & Pernah & 2500 \\
\hline 5 & 25 & S1 & Normal & 39 & 1 & 0 & Tidak & 2700 \\
\hline$\ldots$ & $\ldots$ & $\ldots$ & $\ldots$ & $\ldots$ & $\ldots$ & $\ldots$ & $\ldots$ & $\ldots$ \\
\hline
\end{tabular}

Gambar 3. Soal 1 Tes Kemampuan Awal Statistis 


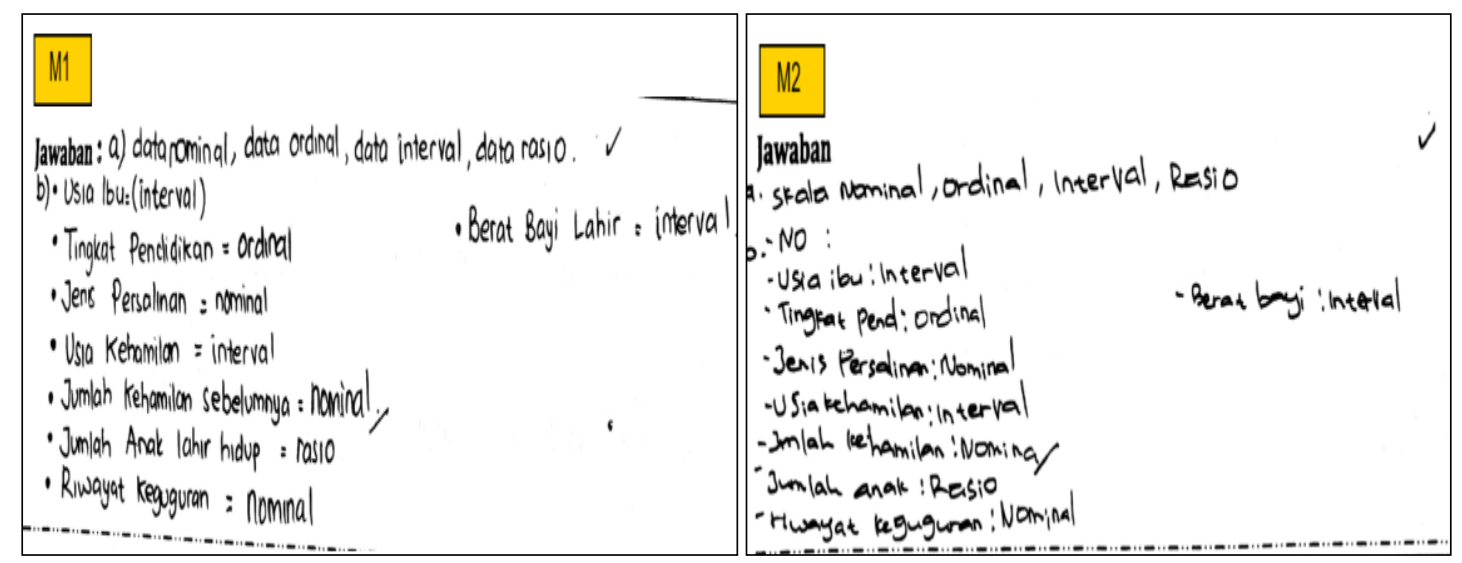

Gambar 4. Hasil Pekerjaan Soal 1 dari Mahasiswa Kategori Level KAS-Tinggi

\section{b. Kelompok Level KAS-Sedang}

M3 dan M4 adalah mahasiswa yang dipilih dari kelompok level KAS-sedang. M3 memberikan jawaban terhadap pertanyaan Soal 1a tetapi belum lengkap memuat empat jenis skala pengukuran. M3 belum menunjukan pemahamannya terhadap perbedaan jenis-jenis skala pengukuran data. Hal itu diperlihatkan dari jawabannya yang masih keliru dalam menentukan jenis skala pengukuran untuk setiap variabel yang ada pada soal.

Mahasiswa M4 memberikan jawaban empat jenis skala pengukuran data dengan benar tetapi belum mampu menerapkannya untuk soal yang diberikan. M4 masih keliru dalam mengidentifikasi dan menentukan jenis skala pengukuran setiap variabel yang ada pada soal.

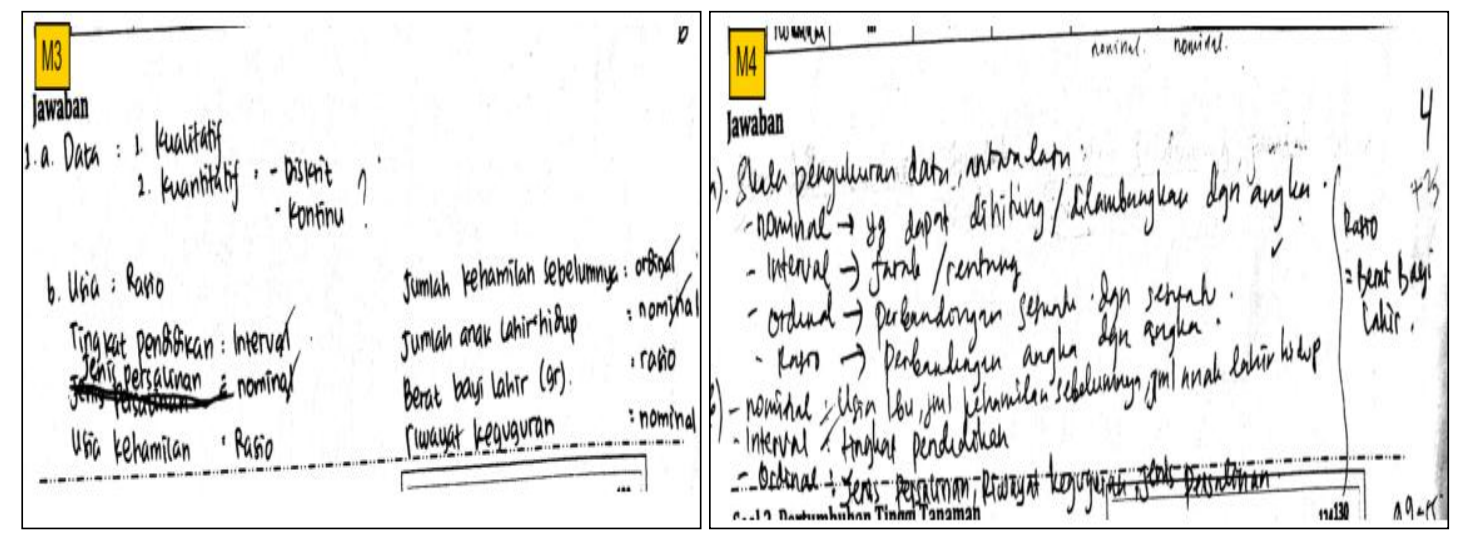

Gambar 5. Hasil Pekerjaan Soal 1 dari Mahasiswa Kategori Level KAS-Sedang

\section{c. Kelompok Level KAS-Rendah}

M5 dan M6 adalah mahasiswa yang dipilih dari kelompok level KAS-rendah. M5 hampir tidak memberikan jawaban terhadap pertanyaan Soal 1a. M5 hanya menuliskan jawaban yang kurang tepat dengan pertanyaan. Jawaban yang diberikan bukan termasuk salah satu jenis skala pengukuran seperti yang seharusnya dituliskan sebagai respon untuk Soal 1a. M5 tidak memberikan jawaban untuk pertanyaan Soal 1b. Diduga bahwa M5 belum memahami masalah yang diberikan, belum mampu memahami konsep dan menerapkannya. 
Mahasiswa M6 menuliskan empat jenis skala pengukuran data dengan benar tetapi belum mampu menerapkannya terhadap soal yang diberikan. M6 masih keliru dalam mengidentifikasi dan menentukan jenis skala pengukuran setiap variabel yang ada pada soal.

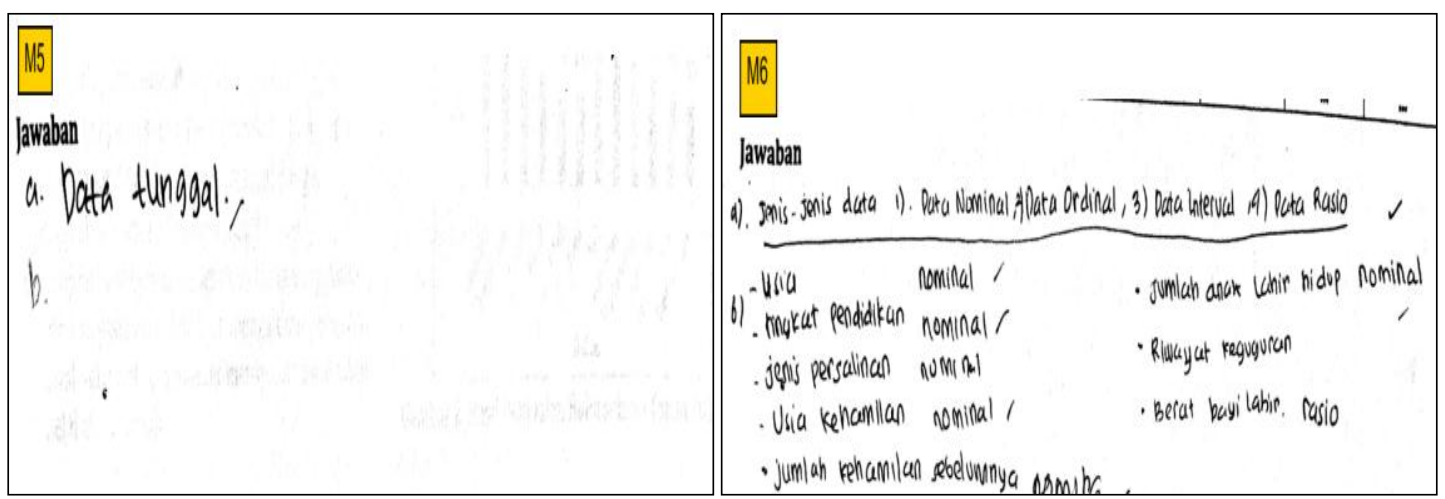

Gambar 6. Hasil Pekerjaan Soal 1 dari Mahasiswa Kategori Level KAS-Rendah

Hasil analisis pekerjaan mahasiswa dari setiap kategori level KAS untuk butir Soal 2, 3, dan 4 disajikan secara ringkas pada Tabel 3.

Tabel 3.

Ringkasan Hasil Analisis Pekerjaan Mahasiswa untuk setiap Soal

\begin{tabular}{|c|c|c|c|}
\hline \multirow{2}{*}{$\begin{array}{l}\text { Mahasiswa } \\
\text { (Level KAS) }\end{array}$} & \multicolumn{3}{|c|}{ Simpulan Hasil Pekerjaan } \\
\hline & Soal 2 & Soal 3 & Soal 4 \\
\hline $\begin{array}{l}\text { M1, M2 } \\
\text { (Tinggi) }\end{array}$ & $\begin{array}{l}\text { berhasil } \\
\text { memberikan } \\
\text { perkiraan } \\
\text { jawaban dengan } \\
\text { menggunakan } \\
\text { proses solusi } \\
\text { yang relevan } \\
\text { dengan } \\
\text { permasalahan. }\end{array}$ & $\begin{array}{l}\text { berhasil memahami } \\
\text { konsep ukuran } \\
\text { pemusatan dan } \\
\text { keterkaitannya serta } \\
\text { dapat memberikan satu } \\
\text { lawan contoh yang } \\
\text { tepat untuk } \\
\text { mendukung jawaban. }\end{array}$ & $\begin{array}{l}\text { berhasil menentukan ukuran statistik } \\
\text { yang disajikan dalam bentuk diagram } \\
\text { batang, menafsirkannya, dan } \\
\text { memberikan kesimpulan yang jelas dan } \\
\text { logis dengan menunjukan cara } \\
\text { pandangnya terhadap permasalahan. }\end{array}$ \\
\hline $\begin{array}{l}\text { M3, M4 } \\
\text { (Sedang) }\end{array}$ & $\begin{array}{l}\text { berhasil } \\
\text { memberikan } \\
\text { perkiraan } \\
\text { jawaban tetapi } \\
\text { belum mampu } \\
\text { menjelaskan } \\
\text { proses solusi } \\
\text { yang diberikan. }\end{array}$ & $\begin{array}{l}\text { berhasil memahami } \\
\text { konsep ukuran } \\
\text { pemusatan dan } \\
\text { keterkaitannya serta } \\
\text { dapat memberikan satu } \\
\text { lawan contoh yang } \\
\text { tepat untuk } \\
\text { mendukung jawaban. }\end{array}$ & $\begin{array}{l}\text { dapat menentukan ukuran statistik yang } \\
\text { disajikan dalam bentuk diagram batang, } \\
\text { menafsirkannya, tetapi kesimpulan } \\
\text { yang diberikan belum cukup jelas. }\end{array}$ \\
\hline $\begin{array}{l}\text { M5, M6 } \\
\text { (Rendah) }\end{array}$ & $\begin{array}{l}\text { belum berhasil } \\
\text { memberikan } \\
\text { perkiraan } \\
\text { jawaban dan } \\
\text { proses } \\
\text { solusinya. }\end{array}$ & $\begin{array}{l}\text { belum dapat } \\
\text { memahami konsep } \\
\text { ukuran pemusatan } \\
\text { sehingga belum dapat } \\
\text { memberikan satu } \\
\text { lawan contoh yang } \\
\text { diminta. }\end{array}$ & $\begin{array}{l}\text { belum dapat menentukan ukuran } \\
\text { pemusatan dari data yang disajikan } \\
\text { dalam bentuk diagram, dan kesimpulan } \\
\text { yang diberikan belum cukup jelas, } \\
\text { masih terbatas, dan tidak } \\
\text { memanfaatkan informasi yang ada }\end{array}$ \\
\hline
\end{tabular}




\section{PEMBAHASAN}

Mahasiswa pada kedua kelas pembelajaran cenderung memiliki prestasi akademis yang sangat memuaskan karena sebaran IPK banyak berkisar dari 3,00 sampai dengan 3,50. Ukuran rata-rata dan simpangan baku data IPK dari mahasiswa di Kelas A dan mahasiswa di Kelas B yang ditampilkan pada Tabel 1 menunjukkan rata-rata IPK mahasiswa di Kelas A cukup berbeda dengan rata-rata IPK mahasiswa di Kelas B. Namun demikian, simpangan baku IPK setiap kelas cukup kecil dapat menunjukkan bahwa mahasiswa pada masing-masing kelas relatif memiliki prestasi akademis yang homogen.

Untuk mengungkapkan pengaruh suatu perlakuan terhadap variabel yang diamati pada penelitian eksperimen atau kuasi-eksperimen, desain yang digunakan merujuk pada (Creswell, 2008, 2014) yaitu membentuk kelompok eksperimen dan kelompok kontrol. Dengan demikian, dua kelas pembelajaran ditentukan menjadi kelompok eksperimen dan kelompok kontrol. Penentuan kelas yang menjadi kelompok eksperimen dan kelas yang menjadi kelompok kontrol dilakukan secara acak, karena berdasarkan hasil pengujian statistik terhadapa data nilai tes penentuan grup menunjukkan bahwa diantara kedua kelas pembelajaran tidak memiliki perbedaan hasil tes tulis.

Secara deskriptif, nilai rata-rata hasil tes KAS pada kelompok eksperimen lebih tinggi dibandingkan dengan kelompok kontrol, meskipun perbedaannya hanya 4,76 poin. Simpangan baku nilai KAS pada kelompok eksperimen lebih kecil dibandingkan dengan kelompok kontrol menjadi indikasi bahwa kemampuan awal statistis mahasiswa pada kelompok eksperimen lebih homogen dibandingkan dengan kemampuan mahasiswa pada kelompok kontrol.

Uji perbedaan rata-rata nilai hasil tes KAS diantara kedua kelompok pembelajaran menghasilkan $t_{\text {hitung }}=1,472(p$-value $=0,148)$. Hasil itu menunjukkan bahwa pada taraf siginifikan $5 \%$ belum cukup bukti untuk menolak $\mathrm{H}_{0}$. Dengan kata lain, dapat dinyatakan bahwa kemampuan awal statistis mahasiswa pada kelompok eksperimen sama dengan kemampuan awal statistis mahasiswa pada kelompok kontrol.

Hasil analisis pekerjaan mahasiswa dari yang memiliki level KAS-tinggi menunjukkan bahwa mereka telah mampu mengenali dan mengidentifikasi konsep skala pengukuran variabel. Mahasiswa dengan level KAS-sedang dapat mengenali konsep skala pengukuran tetapi cenderung belum mampu menerapkannya secara praktis. Mahasiswa yang memiliki level KAS-rendah belum dapat mengenali dan mengidentifikasi konsep yang ada pada permasalahan dan belum dapat menerapkannya terhadap permasalahan.

Berdasar pada hasil eksplorasi kemampuan awal statistis mahasiswa pada topik statistika deskripsi dalam penelitian ini, maka indikator yang masih belum mendapat capaian maksimal pada setiap level KAS perlu menjadi perhatian. Indikator-indikator tersebut dapat dibahas ulang di kelas, melalui diskusi atau pengerjaan beberapa latihan soal yang relevan untuk memperbaiki atau memperkuat pemahaman mahasiswa terhadap pengetahuan awal yang diperlukan pada pembelajaran selanjutnya. Pengetahuan awal pada materi statistika deskripsi merupakan salah satu pengetahuan awal yang diperlukan untuk mengikuti pembelajaran selanjutnya yaitu mempelajari materi stastistika inferensi.

\section{SIMPULAN}

Eksplorasi terhadap hasil pekerjaan mahasiswa dalam menyelesaikan tes tulis kemampuan awal statistis mengungkapkan adanya perbedaan cara kerja dalam menghadapi informasi statistik dan perbedaan kemampuan awal mahasiswa dalam menyelesaikan permasalahan statistika deskriptif. Kemampuan awal statistis (KAS) mahasiswa dibedakan menjadi tiga level. Mahasiswa dengan level KAS-tinggi, cenderung berhasil memahami konsep skala pengukuran dan menerapkannya secara tepat terhadap permasalahan, 
mampu memperkirakan jawaban dan proses solusi dengan cara yang logis, telah memahami konsep dan keterkaitan ukuran-ukuran pemusatan, serta dapat menafsirkan informasi statistik dan memberikan kesimpulan yang relevan dengan cara pandang mereka terhadap permasalahan. Mahasiswa dengan level KAS-rendah, cenderung sudah cukup mampu memahami konsep skala pengukuran tetapi belum dapat menerapkannya, dapat menentukan ukuran-ukuran statistik dan memperkirakan jawaban namun dengan proses yang belum diungkapkan secara jelas, informasi statistik cenderung diinterpretasikan secara terbatas tanpa memanfaatkan informasi dan wawasan yang terkait dengan permasalahan.

Berdasar pada analisis terhadap hasil pekerjaan mahasiswa dalam menyelesaikan statistika deskriptif, ada beberapa materi yang perlu diperhatikan untuk pembelajaran selanjutnya khususnya pada topik statistika inferensial. Materi itu antara lain adalah pengulangan pada materi penentuan skala pengukuran data atau variabel. Penentuan skala pengukuran suatu variabel perlu diperhatikan karena tipe skala pengukuran data atau variabel akan menentukan alat uji hipotesis yang sesuai untuk digunakan pada materi statistika inferensial.

Penelitian ini masih terbatas pada hasil eksplorasi tentang kemampuan awal statistis mahasiswa dalam topik statistika deskriptif dari hasil tes tulis (dokumen) mahasiswa. Untuk selanjutnya, perlu dilakukan tambahan metode lain untuk mendapatkan data dan analisisnya, antara lain dengan wawancara mendalam terhadap partisipan. Diharapkan melalui wawancara dapat diperoleh informasi yang belum terlihat pada lembar hasil tes tulis mahasiswa terkait pekerjaannya sehingga kemampuan awal statistis mahasiswa dapat diungkapkan lebih banyak.

Kemampuan awal statistis mahasiswa yang cenderung masih beragam dalam menyelesaikan permasalahan topik statistika deskriptif menjadi faktor penting yang perlu menjadi perhatian untuk melaksanakan pembelajaran selanjutnya. Materi atau konsep yang belum dipahami oleh mahasiswa dapat diberikan perhatian lebih agar kemampuan penalaran statistis pada materi pembelajaran selanjutnya dapat dicapai secara optimal.

\section{UCAPAN TERIMA KASIH}

Penulis menyampaikan ucapan terima kasih yang tak terhingga kepada semua validator yang telah banyak memberikan saran dan masukan serta memvalidasi instrumen kemampuan awal statistik. Terima kasih juga disampaikan kepada tim pengampu mata kuliah yang telah banyak bekerja sama dalam menyelesaikan penelitian. Selain itu, ucapan terima kasih juga ditujukan kepada pimpinan universitas tempat penelitian dilaksanakan. Ucapan terima kasih yang khusus juga disampaikan untuk seluruh mahasiswa yang telah berpartisipasi aktif dalam penelitian.

\section{DAFTAR RUJUKAN}

Bateiha, S., Marchionda, H., \& Autin, M. (2020). Teaching style and attitudes: a comparison of two collegiate introductory statistics classes. Journal of Statistics Education, 0(0), 1-16. https://doi.org/10.1080/10691898.2020.1765710

Ben-Zvi, D. (2011). Statistical Reasoning Learning Environment. EM TEIA, 2(2011).

Ben-Zvi, D., \& Garfield, J. (2004). The Challenge of Developing Statistical Literacy, Reasoning, and Thinking (D. Ben-Zvi \& J. Garfield, Eds.). New York: Kluwer Academic Publisher.

Castro, F. G., Kellison, J. G., Boyd, S. J., \& Kopak, A. (2010). A Methodology for Conducting Integrative 
Mixed Methods Research and Data Analyses. Journal of Mixed Methods Research, 4(4), 342-360. https://doi.org/10.1177/1558689810382916

Creswell, J. W. (2008). Educational Research: Planning, Conducting, and Evaluating Quantitative and Qualitative Research (Third). Boston: Pearson International Edition.

Creswell, J. W. (2014). Research Design Qualitative, Quantitative, and Mixed Method Approaches. London: SAGE Publications Ltd.

DelMas, R. C. (2002). Statistical Literacy, Reasoning, and Learning: A Commentary. Journal of Statistics Education, 10(3). Retrieved from http://www.amstat.org/publications/jse/v10n3/delmas_discussion.html

DelMas, R. C. (2006). Defining and Distinguishing Statistical Literacy, Statistical Reasoning, and Statistical Thinking. Retrieved October 16, 2015, from https://apps3.cehd.umn.edu/artist/glossary.html website: https://apps3.cehd.umn.edu/artist/glossary.html

Dochy, F., Segers, M., \& Buehl, M. M. (1999). The Relation Between Assessment Practices and Outcomes of Studies: The Case of Research on Prior Knowledge. Review of Educational Research, 69(2), 145186. https://doi.org/10.3102/00346543069002145

Furr, R. M. (2011). Scale Construction and Psychometrics for Social and Personality Psychology. https://doi.org/10.4135/9781446287866

Garfield, J. (1993). Teaching Statistics Using Small - Group Cooperative Learning. Journal of Statistics Education, 1(1), 1-8.

Garfield, J. (1995). How Students Learn Statistics. International Statistical Review, 63(1), $25-34$. https://doi.org/10.2307/1403775

Garfield, J. (2002). The Challenge of Developing Statistical Reasoning. Journal of Statistics Education, 10(3), 1-10.

Gurlitt, J., \& Renkl, A. (2010). Prior knowledge activation: How different concept mapping tasks lead to substantial differences in cognitive processes, learning outcomes, and perceived self-efficacy. Instructional Science, 38(4), 417-433. https://doi.org/10.1007/s11251-008-9090-5

Hair, J. F., Black, W. C., Babin, B. J., \& Anderson, R. E. (2010). Multivariate Data Analysis. https://doi.org/10.1016/j.ijpharm.2011.02.019

Jackson, S. L. (2006). Research Methods and Statistics: a Critical Thinking Approach. United States: Thomson Wadsworth.

Kadambari, D., Kumar, S., Zayapragassarazan, Z., \& Parija, S. (2018). Using Research and Evidence. In Improving Discipline-Based Undergraduate Medical Curriculum. https://doi.org/10.1007/978-981-131310-3_2

Kanga, A., Njeru, L. N., Wachera, E., \& Jedidah. (2015). Rethinking variant models of embedded research design within a qualitative dominant mixed method study. General Education Journal, 4(September), $15-31$.

Kerlinger, F. N. (1986). Foundation of Bahavioural Research (Indonesian; H. J. Koesoemanto, Ed.). Yogyakarta: Gadjah Mada University Press.

Li, L. (2018). Effect of Prior Knowledge on Attitudes , Behavior , and Learning Performance in Video 
Lecture Viewing Effect of Prior Knowledge on Attitudes, Behavior, and Learning Performance in. International Journal of Human-Computer Interaction, O0(00), 1-12. https://doi.org/10.1080/10447318.2018.1543086

Nadiyah, S., Wijaya, F. Y., \& Hakim, A. R. (2019). Desain Komik Strip Matematika pada Materi Statistika untuk Kelas VI Tingkat Sekolah Dasar. Jurnal Kajian Pendidikan Matematika, 2682(2), 135-146.

Park, R. (2018). Practical Teaching Strategies for Hypothesis Testing. The American Statistician, 1305, 0. https://doi.org/10.1080/00031305.2018.1424034

Rohana, \& Ningsih, Y. L. (2020). Students' Statistical Reasoning in Statistics Method Course. Jurnall Pendidikan Matematika, 14(1), 81-90.

Ruseffendi, H. E. T. (2005). Dasar-Dasar Penelitian Pendidikan dan Bidang Non Eksakta Lainnya. Bandung: PT. Tarsito.

Sekaran, U. (2006). Research Methods for Business (terjemahan): Metodologi Penelitian untuk Bisnis (4th ed.; K. M. Yon, Ed.). Jakarta: Penerbit Salemba EMpat.

Sekaran, U., \& Bougie, R. (2013). Research Methods for Business (6th ed.). United Kingdom: John Wiley \& Sons Ltd.

Thompson, P., \& Liu, Y. (2005). Teachers' understandings of hypothesis testing. Proceedings of the TwentySeventh Annual Meeting of the International Group for the Psychology of Mathematics Education. Vicksburg: Virginia Tech.

Valstar, S., Griswold, W. G., \& Porter, L. (2019). The Relationship between Prerequisite Proficiency and Student Performance in an Upper-Division Computing Course. 794-800.

Walpole, R. E., Myers, R. H., \& Myers, S. L. (2011). Probability \& Statistics for Engineers \& Scientis. Boston: Prentice Hall. 